\title{
POLA DISTRIBUSI MITOKONDRIA SEL-SEL TROFOBLAS BLASTOSIS MENCIT (Mus Muculus Albinus) DAN PENGARUHNYA TERHADAP KEGAGALAN HATCHING DAN IMPLANTASI
}

\author{
Roza Helmita ${ }^{1}$, Ita Djuwita ${ }^{2}$, Bambang Purwantara ${ }^{3}$, Adi Winarto ${ }^{2}$ \\ ${ }^{1}$ Program Studi Tadris Biologi, Fakultas Tarbiyah, IAIN Batusangkar.Jl Sudirman No. 137 Kubu \\ Rajo Lima Kaum Batusangkar Sumatera Barat 27213. ${ }^{2}$ Bagian Anatomi, Histologi dan Embriologi, \\ Departemen Anatomi, Fisiologi dan Farmakologi Fakultas Kedokteran Hewan, Institut Pertanian \\ Bogor. ${ }^{3}$ Bagian Fisiologi Reproduksi dan Kebidanan, Departemen Klinik, Reproduksi dan \\ Patologi, Fakultas Kedokteran Hewan, Institut Pertanian Bogor. \\ Email: helmitaroza@gmail.com
}

\begin{abstract}
Implantation is the most critical stage in the establishment of pregnancy. In mammals, it has been estimated that between $25 \%$ and $60 \%$ of conceptuses are lost before or at the time of implantation. The objectives of this study were to investigate the ability of blastocyst hatching and attachment of trophoblast cells in in vitro, the outgrowth and differentiation of trophoblast cells in in vitro culture of hatched and non hatched blastocyst, the activity of mitochondria NADH-CoQ reductase and the pattern of mitochondrial distribution. Blastocysts were collected from mice cornua utery at day-4 of pregnancy and were divided into 3 groups: blastocysts undergo hatching within 24 hours, 48 hours and non hatching. Embryos were cultured in DMEM medium in 5\% $\mathrm{CO}_{2}$ incubator at $37^{\circ} \mathrm{C}$ for 10 days. The trophoblasts monolayer were processed for Giemsa staining and histochemistry analysis of NADH-tetrazolium reductase activity. The outgrowth of trophoblast cells were measured using eyespiece micrometer. The results showed the ability of blastocyst hatching in in vitro were different. The trophoblast outgrowth diameter of $24 \mathrm{~h}$ hatched blastocyst was significantly different with the $48 \mathrm{~h}$ hatched and non hatched blastocyst. The activity of NADH-CoQ reductase of $24 \mathrm{~h}$ and $48 \mathrm{~h}$ hatched blastocysts showed higher intensity than the non hatched blastocysts $(\mathrm{P}<0,05)$ and the distribution of mitochondrial in trophoblast cell cytoplasma of $24 \mathrm{~h}$ and $48 \mathrm{~h}$ hatched blastocyst were homogen around nucleus whereas thoes of non hatched blastocyst were cluster and heterogen. In conclusion, in in vitro study the failure of blastocysts hatching and implantation was due to the failure of outgrowth and differentiation of the trofoblast cells and the impairment of NADH-CoQ reductase activity in complex I mitochondria to produce energy and the pattern of mitochondrial distribution.
\end{abstract}

Key words: mitochondrial distribution, $\mathrm{NADH}$ - tetrazolium reductase, trophoblast, implantation

\section{PENDAHULUAN}

Implantasi merupakan suatu peristiwa dalam reproduksi mamalia yang menentukan apakah kebuntingan akan dapat dipertahankan sampai lahir. Untuk mencapai tahap implantasi, embrio tahap blastosis harus mengalami hatching yakni proses keluarnya embrio dari zona pelusida (Dey et al 2004; Horse et al. 2004). Blastosis hatching terdiri dari inner cell mass (ICM) yang akan menjadi fetus sedangkan lapisan epitel paling luar yaitu trofoblas (Aplin \& Kimber 2004). Selanjutnya ketahap adhesi dan nidasi (perlekatan sel-sel trofoblas ke dinding endometrium), proliferasi, diferensiasi, infiltrasi dan invasi sel-sel trofoblas ke dalam endometrium.

Perkembangan embrio praimplantasi ada kalanya mengalami gangguan, sehingga tidak semua embrio praimplantasi dapat mengalami 
'hatching' dan implantasi. Hal ini ditunjukkan dari hasil transfer blastosis manusia yaitu hanya sekitar 47\%-60\% yang berhasil mengalami implantasi dan hamil (Fong et al. 2001; Summer \& Bigger 2003). Bahkan Norwitz et al. (2001) mengemukakan bahwa blastosis yang dikultur in vitro kemudian ditransfer, menunjukkan tingkat implantasi sekitar $25 \%$. Sedangkan Hredzak et al. (2005) menyatakan bahwa pada mencit tingkat implantasi embrio segar $31,3 \%$ dan embrio vitrifikasi $11,1 \%$.

Selama perkembangan embrio praimplantasi dari zigot sampai mencapai blastosis, terjadi peningkatan aktivitas metabolisme serta kebutuhan energi (Trimarchi et al. 2000; Ludwig et al. 2001; Blerkom 2004; Acton et al. 2004). Proses pembentukkan energi sangat berhubungan erat dengan aktivitas mitokondria sebagai organel pembangkit energi dalam sel (power house cell) sehingga gangguan atau rusaknya mitokondria dapat mempengaruhi proses pembentukkan energi yang sangat dibutuhkan dalam proses 'hatching' dan implantasi blastosis. Didalam mitokondria pembentukan energi berupa adenosin triphosfat (ATP) terjadi melalui dua interaksi siklus metabolisme, yaitu siklus asam sitrat (siklus kreb's) dan oksidasi fosforilasi (Klobuear dan Gorup 2004; Brookes 2004; Malik et al 2000; Tamassia et al 2004). Salah satu produk dari siklus asam sitrat adalah nicotinamide adenin dinucleotide dehydrogenase (NADH) yang berfungsi sebagai substrat pada reaksi transduksi energi dalam sistem rantai transpor elektron (RTE) atau okidasi fosforilasi. Pelepasan energi NADH terjadi secara bertahap dengan melibatkan enzim-enzim seperti NADH-CoQ reductase pada kompleks I (Dimauro dan Schon 2003; Trimarchi et al. 2000; Blerkom 2004; Brookes et al. 2004).

Walaupun kajian dan informasi terhadap proses implantasi secara in vitro telah banyak dilaporkan, namun kajian in vitro mengenai kegagalan 'hatching' dan implantasi yang dikaitkan dengan kemampuan mitokondria menghasilkan energi untuk pertumbuhan dan diferensiasi sel-sel trofoblas belum dilaporkan.

Penelitian ini bertujuan untuk mempelajari dan memperoleh informasi mengenai: (1) kemampuan outgrowth sel-sel trofoblas, (2) aktivitas NADH-CoQ reductase mitokondria serta (3) pola distribusi mitokondria dari sel-sel trofoblas yang mengalami 'hatching' dan gagal 'hatching' dalam medium kultur in vitro.

Hasil penelitian ini diharapkan dapat memberi informasi dasar mengenai pengaruh aktivitas mitokondria yang pada penelitian ini mengkhususkan terhadap aktivitas NADH-CoQ reductace mitokondria selama proses implantasi embrio serta pola sebaran mitokondria sel-sel trofoblas untuk tumbuh dan berdiferensiasi terhadap kegagalan hatching dan implantasi.

\section{BAHAN DAN METODE \\ Rancangan Percobaan}

Penelitian ini menggunakan rancangan acak lengkap (RAL). Blastosis mencit dibagi kedalam tiga perlakuan, yaitu: (1) blastosis yang 'hatching' cepat (24 jam), (2) blastosis yang 'hatching' lambat (48 jam) dan (3) blastosis yang gagal 'hatching'. Masing-masing kelompok dikultur sampai membentuk monolayer selama 10 hari, selanjutnya diukur penjuluran sel-sel trofoblas (outgrowth), diidentifikasi morfologi sel-sel trofoblas yang mengalami diferensiasi dan aktivitas NADHCoQ reductase secara histokimia serta distribusi mitokondria secara imunositokimia. Masingmasing perlakuan menggunakan minimal 10 embrio.

\section{Koleksi Blastosis}

Mencit putih (Mus muculus albino) dara strain DDY umur 6-8 minggu disuperovulasi dengan penyuntikan hormon Pregnant mare's serum gonadotrophin (PMSG, Folligon $®$, Intervet, Netherland) dengan dosis 5 IU/ekor dan 46 jam kemudian disuntik dengan hormon human chorionic gonadotrophin (hCG, Chorulon ${ }^{\circledR}$, Intervet, Netherland) (dengan dosis yang sama) secara intraperitoneal (i.p.). Setelah penyuntikan hCG, mencit betina dikawinkan dengan pejantan dengan perbandingan jantan : betina 1:1. Mencit betina yang telah dikawini pejantan dicirikan oleh adanya sumbat vagina (masa perkejuan berwarna putih kekuningan di dalam lumen vagina) pada 18 jam pasca hCG dan dianggap sebagai hari pertama kebuntingan. Mencit betina dimatikan 96-98 jam pasca hCG dengan cara dislocatio cervicalis. Blastosis diperoleh dengan cara membilas (flushing) kedua kornua uterus dengan menggunakan spuit $1 \mathrm{cc}$ yang berisi 
medium Modified Phosphat Buffered Saline (mPBS). Selanjutnya embrio dicuci sebanyak tiga kali di dalam larutan mPBS (Hogan et al. 1994).

\section{Kultur Blastosis Secara In Vitro}

Blastosis yang terkoleksi dimasukkan ke dalam $20 \mu \mathrm{l}$ medium tetes pada cawan petri steril yang ditutupi dengan mineral oil. Medium yang dipakai adalah Tissue Culture Medium (TCM 199 Gibco-BRL) yang diberi gentamicin $50 \mu \mathrm{g} / \mathrm{ml}$ medium, New Born Calf Serum (NBCS) 20\%. Proses kultur dilakukan di dalam inkubator $\mathrm{CO}_{2} 5 \%$ pada suhu $37^{\circ} \mathrm{C}$ selama 2448 jam sampai blastosis mengalami 'hatching'. Blastosis yang gagal 'hatching' dan masih hidup dibantu proses 'hatching' nya dengan menggunakan enzim pronase $0,05 \%$ (Sigma, USA). Kultur selanjutnya dilakukan dengan menggunakan Dubellco's Modified Eagles' Medium (DMEM Gibco-BRL) yang ditambahkan $50 \mu \mathrm{g} / \mathrm{ml}$ gentamicin, NBCS $20 \%$, $1 \mu \mathrm{l} / \mathrm{ml}$ ITS (kandungan insulin $5 \mu \mathrm{g} / \mathrm{ml}$, tranferin $10 \mu \mathrm{g} / \mathrm{ml}$, selenium $5 \mu \mathrm{g} / \mathrm{ml}$; Sigma St Louis USA) dan B-mercaptoethanol 14,3 mM (Sigma St Louis USA). Blastosis dikultur selama 10 hari sampai sel-sel trofoblas membentuk monolayer.

\section{Pengukuran Outgrowth Sel-Sel Trofoblas}

Dalam medium kultur in vitro sel-sel trofoblas akan tumbuh dan melakukan penjuluran ke arah eksternal, yang diistilahkan dengan outgrowth. Pengukuran areal Outgrowth sel-sel trofoblas menggunakan eyespiece micrometer dengan mengukur panjang pertumbuhan sel-sel trofoblas mulai dari batas luar ICM sampai batas luar sel trofoblas dibawah mikroskop inverted cahaya.

\section{Aktivitas NADH- CoQ Reductase dengan Pewarnaan Histokimia}

Aktivitas NADH-CoQ reductase dideteksi dengan pewarnaan histokimia yang dilihat dari aktivitas NADH-tetrazolium reductase berdasarkan metode Malik et al (2000) dengan modifikasi. Penilaian aktivitas NADH-TR dilakukan berdasarkan pengamatan intensitas warna biru dari nitroblue tetrazolium pada sel-sel trofoblas yakni: (1) biru tua, (2) biru, (3) biru muda, dan (4) tidak berwarna biru. Warna biru tua yang ditimbulkan menggambarkan bahwa fungsi mitokondria pada sistem transpor elektron dalam kondisi sangat baik. Bila tidak atau sangat sedikit menghasilkan warna biru menggambarkan adanya gangguan atau disfungsi pada mitokondria terutama pada sistem transpor elektron khususnya kompleks I (NADH-CoQ reductase) dalam membentuk energi.

Pemeriksaan aktivitas NADH- TR secara histokimia dilakukan dengan cara sebagai berikut:

1. Monolayer sel-sel blastosis diinkubasi pada suhu $37^{\circ} \mathrm{C}$, dalam campuran pereaksi yang terdiri dari: $0,2 \mathrm{~mol} / \mathrm{L}$ buffer fosfat $(\mathrm{pH}$ $7,4)$ yang mengandung $0,1 \mathrm{~mol} / \mathrm{L}$ sodium laktat, $0,1 \%$ laktat dehydrogenase (LDH; Boehringer Mannheim), 0,5 mg/ml NAD (Boehringer Mannheim) dan 0,5 $\mathrm{mg} / \mathrm{ml}$ nitroblue tetrazolium (NBT; Boehringer Mannheim), selama 60 menit dalam suasana gelap.

2. Reaksi enzim NADH-tetrazolium reductase dihentikan dengan mencuci kultur monolayer sel dengan buffer fosfat $0,05 \mathrm{~mol} / \mathrm{L}$. NADH-TR akan mengubah NBT yang tidak berwarna menjadi produk reduksi yang berwarna biru. Pengamatan dilakukan terhadap intensitas perbedaan warna biru diantara tiga kelompok perlakuan.

\section{Imunositokimia Terhadap Mitokondria}

Slide dicuci menggunakan PBS pH 7,4 satu kali selama 5 menit. Bloking endogenous peroksida menggunakan $3 \% \mathrm{H}_{2} \mathrm{O}_{2}$ selama 20 menit. Cuci menggunakan PBS pH 7,4 tiga kali, masing-masing selam 5 menit. Bloking unspesifik protein menggunakan 5\% FBS yang mengandung $0,25 \%$ Triton $\mathrm{X}-100$ Cuci menggunakan PBS pH 7,4 tiga kali, masingmasing selam 5 menit. Inkubasi menggunakan mouse monoclonal anti mitokondria semalam pada suhu $4{ }^{\circ} \mathrm{C}$. Cuci menggunakan PBS pH 7,4 tiga kali, masing-masing selam 5 menit. Inkubasi menggunakan anti mouse conjugated selama satu jam pada suhu ruang. Cuci menggunakan PBS pH 7,4 tiga kali, masingmasing selam 5 menit. Inkubasi menggunakan SA-HRP (Strep-Avidin Horse Radis Peroxidase) selama 40 menit. Cuci menggunakan PBS pH 7,4 tiga kali, masingmasing selam 5 menit. Tetesi dengan DAB (Diamino Benzidine) dan inkubasi selama 10 menit. Cuci menggunakan PBS pH 7,4 tiga kali, masing-masing selam 5 menit. Counterstaining 
menggunakan Mayer Hematoxilen yang diinkubasi selama 10 menit dan cuci menggunakan akuades, kemudian dilakukan pengamatan pada mikroskop cahaya.

\section{Analisis Data}

Data Outgrowth sel trofoblas dan data tentang aktivitas NADH-CoQ reductase diuji dengan analisis keragaman dan dilanjutkan dengan uji Beda Nyata Terkecil (BNT) menggunakan software Statistic Analyses System (SAS 2000). Sedangkan data morfologi sel-sel trofoblas yang mengalami diferensiasi dan pola distribusi mitokondria sel-sel trofoblas berupa data kualitatif, dianalisis secara deskriptif.

\section{HASIL DAN PEMBAHASAN} Pertumbuhan (Outgrowth) Sel-Sel Trofoblas (kultur di dalam cawan petri), tidak semua kejadian tersebut terjadi tetapi hanya terbatas pada proses 'hatching', adhesi, perlekatan, yang diikuti dengan pertumbuhan (outgrowth) dan diferensiasi sel-sel trofoblas. Outgrowth dan diferensiasi sel-sel trofoblas tersebut dapat dianalogkan dengan proses invasi secara in vivo, sedangkan proses infiltrasi tidak teramati karena sistem kultur yang digunakan tidak dilapisi feeder layer yang bertindak sebagai dinding endometrium (Babawale et al. 2002).

Blastosis 'hatching' yang dikultur secara in vitro mengalami proses adhesi dan perlekatan dalam waktu 24 hingga 48 jam, sedangkan mitosis dan proliferasi sel-sel trofoblas tampak setelah 48 jam kultur sehingga terjadi peningkatan diameter outgrowth sel-sel trofoblas membentuk monolayer dengan arah radial yang tidak beraturan (Gambar 1). Pada blastosis gagal 'hatching', adhesi dan perlekatan terjadi setelah dibantu 'haching' nya dengan pronase $0,05 \%$ dalam waktu 24 hingga 48 jam. Akan tetapi mitosis dan proliferasi berjalan sangat lambat sehingga monolayer tidak terbentuk dengan baik. endometrium. Sedangkan lingkungan in vitro
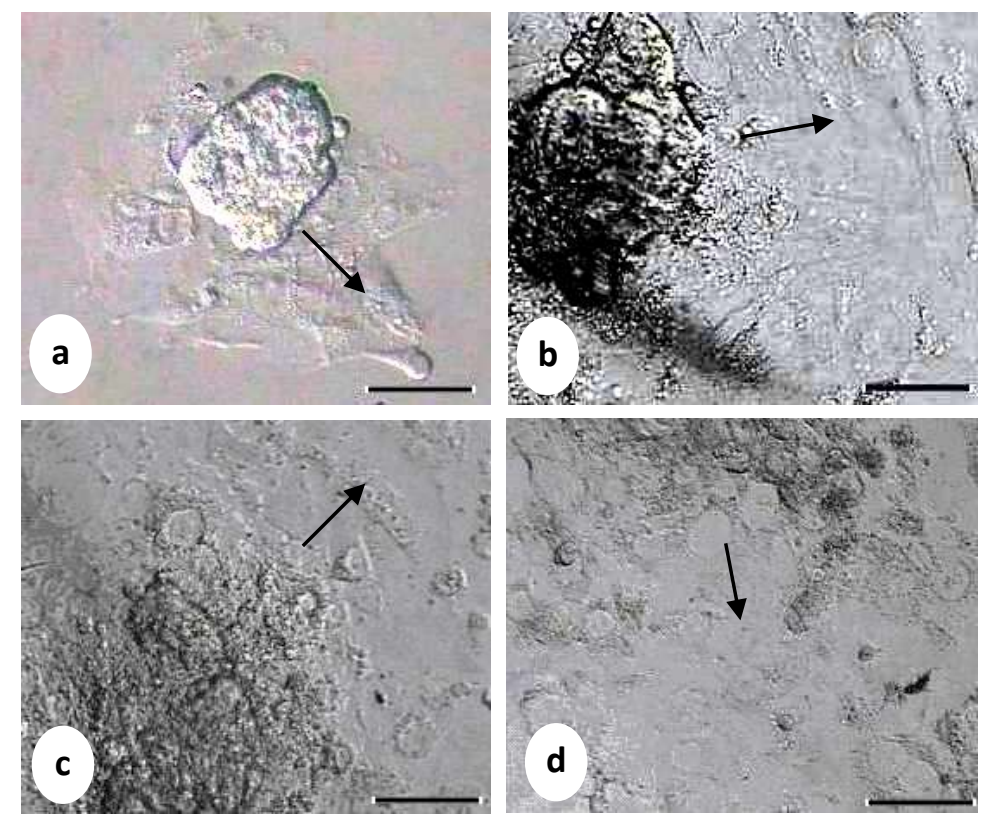

Gambar 1 Pertumbuhan sel-sel trofoblas didalam medium kultur in vitro. (a) Hari ke-2,

(b) Hari ke-5, (c) Hari ke-7 dan (d) Hari ke-10. Bar: 100 $\mu$ m. Tanda panah menunjukkan arah pertumbuhan sel-sel trofoblas dalam bentuk monolayer yang tidak beraturan. 
Kemampuan pertumbuhan sel-sel trofoblas yang dihasilkan oleh blastosis 'hatching' dan gagal 'hatching' sangat berbeda, yang ditunjukkan oleh adanya perbedaan outgrowth sel-sel trofoblas. Hasil pengukuran pada hari ke-10 kultur menunjukkan bahwa outgrowth sel-sel trofoblas yang dihasilkan oleh blastosis yang 'hatching' pada 24 jam mencapai $652,6 \pm 306 \mu \mathrm{m}$ dan berbeda nyata $(\mathrm{P}<0,05)$ dengan outgrowth sel-sel trofoblas dari blastosis yang 'hatching' pada 48 jam dan gagal 'hatching' yakni masing-masing 322,9 $\pm 87 \mu \mathrm{m}$ dan 180,2 $\pm 60 \mu \mathrm{m}$ (Tabel 1). Hal ini menunjukkan bahwa kegagalan 'hatching' yang terjadi pada suatu individu blastosis juga berkaitan erat dengan kemampuan pertumbuhan sel khususnya sel-sel trofoblas.

Tabel 1 Kapasitas Outgrowth Sel-Sel Trofoblas

\begin{tabular}{ccc}
\hline Waktu Hatching (jam) & Jumlah Blastosis & Mean \pm SD $(\mu \mathrm{m})$ \\
\hline 24 & 15 & $652.6 \pm 306^{\mathrm{a}}$ \\
48 & 10 & $322.9 \pm 87^{\mathrm{b}}$ \\
Gagal hatching & 12 & $180.2 \pm 60^{\mathrm{c}}$ \\
\hline
\end{tabular}

Superscript yang berbeda pada kolom yang sama menunjukkan perbedaan yang nyata $(\mathrm{P}<0,05)$

Rendahnya kemampuan pertumbuhan sel-sel trofoblas dari blastosis gagal 'hatching' disebabkan oleh ketidak-mampuan mitokondria untuk menghasilkan energi yang cukup untuk pertumbuhan sel, yang ditunjukkan oleh rendahnya aktivitas enzim NADH-CoQ reductase pada sel-sel trofoblas blastosis gagal 'hatching'. Hal ini didukung pula oleh pernyataan Lunghi et al. (2007), dimana kurangnya produksi energi pada awal implantasi dapat menghambat proliferasi dan diferensiasi sel-sel trofoblas.

\section{Identifikasi Aktivitas NADH-CoQ Reductase}

'Hatching' merupakan suatu proses blastosis keluar dari zona pelusida yang membungkusnya. Proses 'hatching' diawali dengan adanya penambahan ukuran blastosul, pertambahan jumlah sel-sel trofoblas dan inner cell mass (ICM), yang selanjutnya berdampak pada semakin besarnya tekanan dari dalam embrio ke arah zona pelusida dan menyebabkan zona pelusida tersebut semakin menipis. Tekanan yang besar tersebut dapat terjadi jika organel mitokondria yang terdapat di dalam sel embrio tersebut mampu menghasilkan energi secara optimal (Harun 2006; Dominguez et al 2005; Jhon 2002; Trimachi et al 2000; Fong et al. 2001).

Hasil identifikasi secara histokimia terhadap aktivitas enzim NADH-CoQ reductase pada sel-sel trofoblas menunjukkan perbedaan intensitas warna yang nyata $(\mathrm{P}<0,05)$ antara blastosis yang 'hatching' 24 dan 48 jam dengan blastosis gagal hatching (Tabel 2).

Tabel 2 Hasil Pewarnaan Histokimia Terhadap Aktivitas NADH-tetrazolium reductase

\begin{tabular}{ccccccc}
\hline \multirow{2}{*}{ Waktu hatching } & Jumlah & \multicolumn{4}{c}{ Intensitas Warna Biru (Skor) } & \multirow{2}{*}{ Rata-rata Skor } \\
\cline { 3 - 6 } & blastosis & 3 & 2 & 1 & 0 & \\
\hline 24 jam & 15 & 15 & 0 & 0 & 0 & $3.0^{\mathrm{a}}$ \\
48 jam & 10 & 10 & 0 & 0 & 0 & $3.0^{\mathrm{a}}$ \\
Gagal hatching & 12 & 0 & 0 & 1 & 11 & $0.08^{\mathrm{b}}$ \\
\hline
\end{tabular}

Superscript yang berbeda pada kolom yang sama menunjukkan perbedaan yang nyata (P < 0.05). Skor 3: Biru tua, 2: Biru, 1: Biru muda, 0: tidak berwarna biru.

Dari 15 blastosis yang 'hatching' pada 24 jam kultur dan 10 blastosis yang 'hatching' pada 48 jam kultur, semuanya (100\%) menunjukkan intensitas warna biru tua (skor 3 ). Disisi lain, 11 dari 12 blastosis yang gagal 'hatching' (91,67 \%) tidak menunjukkan 
intensitas warna biru (skor 0) dan hanya 1 blastosis $(0,08 \%)$ menunjukkan intensitas warna biru muda (skor 1) (Gambar 2). Hal ini mengindikasikan bahwa aktivitas NADH-CoQ reductase pada sel-sel trofoblas blastosis yang mampu 'hatching' lebih tinggi dibandingkan dengan blastosis gagal 'hatching'. Dengan kata lain, kemampuan 'hatching' berkorelasi positif dengan aktivitas enzim NADH-CoQ reductase pada mitokondria, dimana semakin tinggi aktivitas enzim tersebut maka jumlah energi yang dihasilkan juga akan semakin banyak, yang selanjutnya energi ini digunakan oleh blastosis tersebut untuk berbagai kebutuhan termasuk untuk 'hatching' dan implantasi.
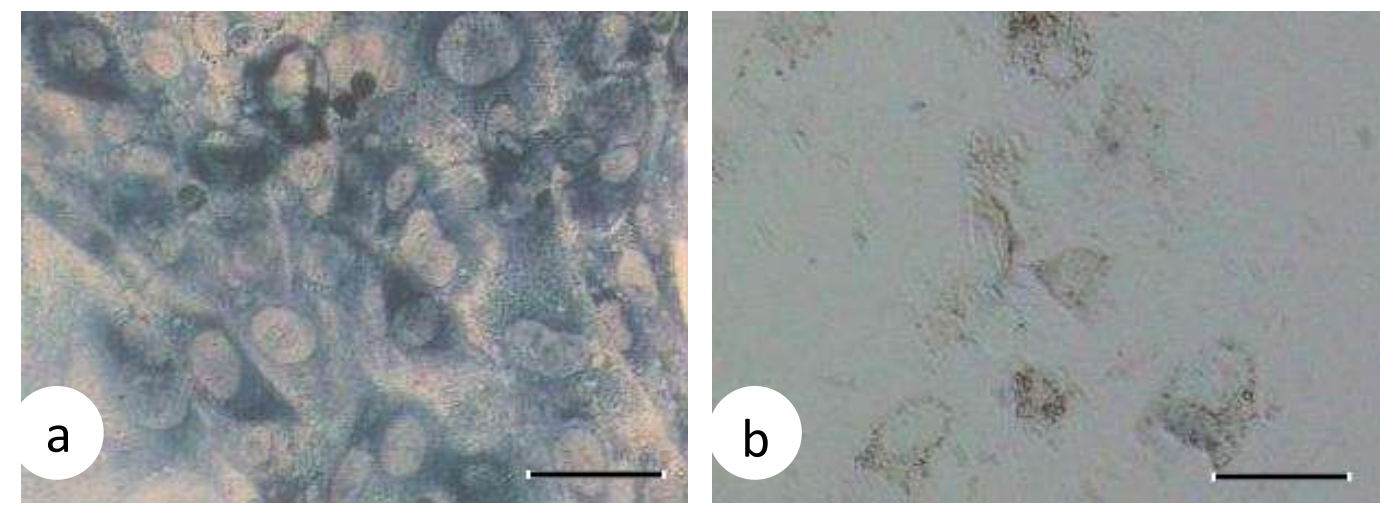

Gambar 2 Aktivitas NADH-CoQ reductase pada monolayer sel-sel trofoblas berdasarkan intensitas warna. (a) sel-sel trofoblas yang dihasilkan oleh blastosis yang 'hatching' pada 24 jam kultur (biru tua), (b) sel-sel trofoblas yang dihasilkan oleh blastosis yang gagal 'hatching' (tidak berwarna). Bar: $100 \mu \mathrm{m}$.

Salah satu produk dari siklus asam sitrat adalah nicotinamide adenin dinucleotide dehydrogenase (NADH) yang berfungsi sebagai substrat pada reaksi transduksi energi dalam sistem rantai transpor elektron (RTE) atau okidasi fosforilasi. Pelepasan energi $\mathrm{NADH}$ terjadi secara bertahap dengan melibatkan enzim-enzim seperti NADH-CoQ reductase pada kompleks I (Davidson 2006; Turren 2003; Vogel et al 2005; Wang 2001). Dengan demikian, jumlah energi yang dihasilkan oleh mitokondria sangat tergantung pada aktivitas enzim NADH-CoQ reductase tersebut. Adanya gangguan pada mitokondria pada komponen kunci rantai transpor elektron seperti NADH-CoQ reductase pada kompleks I dapat mengakibatkan terganggu atau tidak terbentuknya elektron sehingga ATP tidak dapat dihasilkan dengan efisien dan dapat mengganggu fisiologis sel. Terganggunya fisiologis sel dapat mengakibatkan sel mengalami lisis atau apoptosis sehingga sel tidak dapat tumbuh dan berdiferensiasi ke proses selanjutnya (Dimauro dan Schon 2003; Klobuear dan Gorup 2004; Blerkom 2004).

\section{Distribusi Mitokondria pada Sel-Sel Trofoblas}

Sel-sel trofoblas untuk dapat proliferasi dan berdiferensiasi menjadi cytotrophoblast dan synsitiotrophoblast memerlukan ATP yang dihasilkan oleh mitokondria yang tersebar dalam sitoplasma sel-sel trofoblas. Semakin banyak ATP yang dibutuhkan maka semakin banyak pula jumlah mitokondria yang terdistribusi di sekitar nukleus sel-sel trofoblas (Nagai et al. 2006; Nadra et al 2006; Straszewski et al 2005). Lokasi distribusi mitokondria dapat menentukan kondisi perkembangan sel. Mitokondria akan berdistribusi secara normal disekitar nukleus sehingga energi yang dihasilkan oleh ATP dapat langsung dimanfaatkan oleh nukleus dan organel lainnya untuk melakukan aktivitas (Nagai et al. 2006; Thouas et al. 2005; Hauft et al. 2003). 
Hasil imunositokimia terhadap mitokondria pada sel-sel trofoblas dari blastosis nidasi dan gagal nidasi terdapat perbedaan pola distribusi mitokondria di sitoplasma sel-sel trofoblas. Pada sel-sel trofoblas yang nidasi mempunyai pola distribusi mitokondria yang homogen yaitu mitokondria tersebar secara merata disekitar nukleus, sedangkan pola distribusi mitokondria dari sel-sel trofoblas yang gagal nidasi yaitu heterogen, tidak tersebar merata tetapi mitokondria tersebar secara acak dan mengelompok pada satu tempat (Gambar 3).

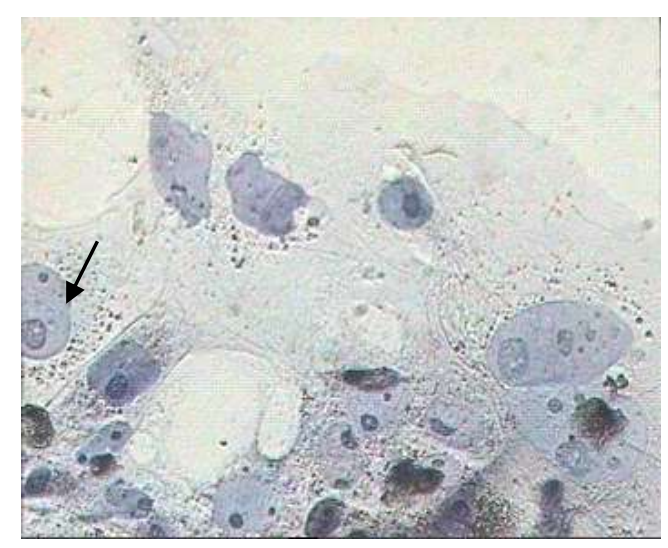

Gambar 3 Pola distribusi $1^{\text {a }}$ ondria pada sel-sel trofoblas. (a) sel-sc b oblas dari blastosis nidasi dengan distribusi mitokondria homogen, (b) sel-sel trofoblas dari trofoblas gagal nidasi dengan distribusi mitokondria yang heterogen. Anak dan kepala panah: menunjukkan pola distribusi mitokondria. Bar: $100 \mu \mathrm{m}$

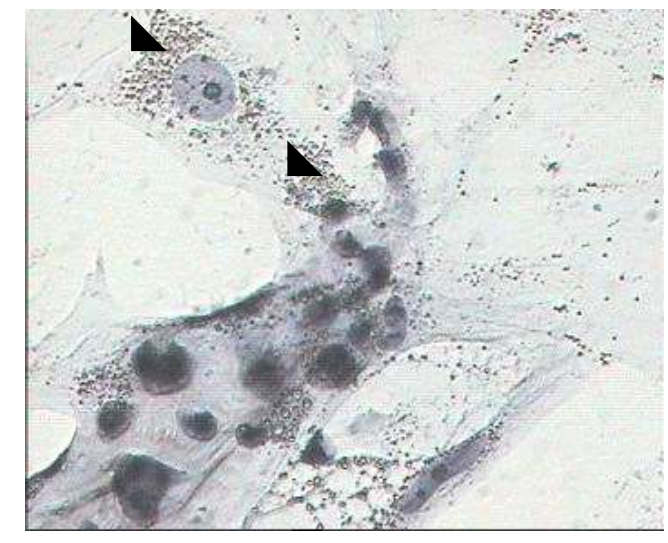

oblas dari blastosis

(1)

Pola distribusi mitokondria yang heterogen pada sel-sel trofoblas dari blastosis gagal nidasi mengindikasikan adanya gangguan distribusi energi (ATP) ke dalam nukleus sehingga nukleus kekurangan energi (ATP) yang diperlukan untuk menjalankan fungsinya, seperti proliferasi dan diferensiasi. Selain itu, pola distribusi mitokondria yang heterogen atau mengelompok dapat dijadikan sebagai indikasi sel akan atau mengalami apoptosis. Hal ini disebabkan dalam proses apoptosis melibatkan mitokondria. Sel yang mengalami apoptosis mempunyai energi (ATP) yang rendah atau menurun (Zeiss 2003). Dengan demikian ATP yang tersedia menjadi sedikit dan berdampak pada pertumbuhan dan aktivitas sel-sel trofoblas. 
sitoplasma sel-sel trofoblas, yakni terdapat pola sebaran mitokondria dengan sebaran homogen untuk sel-sel trofoblas blastosis yang berhasil implantasi dan heterogen untuk yang gagal implantasi.

\section{DAFTAR KEPUSTAKAAN}

Acton BM, Jurisicova A, Jurisica I, Casper RF. 2004. Alterations in mitochondrial membrane potential during preimplantation stages of mouse and human embryo development. Mol Hum Reprod. 10 (1) : 23-32.

Aplin JD, Kimber SJ. 2004. Trophoblastuterine interactions at implantantion. Reprod Biol Endocrinol. 2: 48 doi: 10.1186/1477-7827-2-48.

Babawale MO, Mobberley MA, Ryder TA, Elder MG, Sullivan MHF.2002. Ultrastructure of the early human fetomaternal interface co-cultured in vitro. Hum Reprod. 17(5): 1351-1357.

Blerkom JV. 2004. Mitochondria in human oogenesis and preimplantation embryogenesis: engines of metabolism, ion regulation and developmental competence. Reproduction. 128: 269280.

Blerkom JV, Cox H, Davis P. 2006. Regulatory roles for mitochondria in the peri-implantation mouse blastocyst: possible origins and developmental significance of differential. Reproduction 131: 961-976.

Brookes PS et al. 2004. Calcium, ATP, and ROS: a mitochondrial love-hate triangle. Am J Physiol Cell Physiol. 287: C817C833.

Cartwright JE et al. 2002. Trophoblast invasion of spiral arteries: A novel in vitro model. Placenta. 23: 232-235.

Collins et al. 2005. ESHRE capri workshop group: Fertility and ageing. Hum Reprod. 11(3): 261-276.

Cummins JM.2001. Mitochondria: Potential roles in embryogenesis and nucleocytoplasmic transfer. Hum Reprod. 7 (2): 217-228.

Davidson M W.2006. Mitochondria. Molecular expression.

http://www.microscopy.fsu.edu/cells/ani mals/mitochondria.html. 26 november 2006.

Dey SK et al. 2004. Molecular cues to implantation. Endocrine Reviews. 25(3): 341-373.

Dimauro S, Schon EA. 2003. Mitochondrial respiratory-chain desease. $N$ Engl $\mathrm{J} \mathrm{Med}$. 348 (26): 2656-2668.

Dominguez F, Ya'ñez-Mo M, Madrid SF, Simo'n C. 2005. Embryonic implantation and leukocyte transendothelial migration: different processes with similar players? The FASEB Journal. 19.

Fong CY et al. 2001. Ultrastructural observations of enzymatically treated human blastocysts: zona-free blastocyst transfer and rescue of blastocysts with hatching difficulties. Hum Reprod.16(3): 540-546.

Gardner DK, Lane M, Schoolcraft WB. 2002.Physiology and culture of the human blastocyst. $J$ Reprod Immun. 55:85-100.

Goetz MZ. 2002. Patterning of the embryo: the first spatial decisions in the life of a mouse. Development. 129:815-829.

Grivennikova VG, Kapustin AN, Vinogradov AD. 2001. Catalytic activity of NADHubiquinone oxidoreductase (Complex I) in intact mitochondria. J. Biol Chemistry. 276 (12) : 9038-9044.

Harun R. 2006. Cytotrophoblast stem cell lines derived from human embryonic stem cells and their capacity to mimic invasive implantation events. Hum Reprod. 21(6): 1349-1358.

Harvey AJ, Kind KL, Thompson JG. 2002. Redox regulation of early embryo development. Reproduction. 123: 479486.

Hashash AHK El dan Kimber SJ. 2004. Trophoblast differentiation in vitro: establishment and characterisation of a serum-free culture model for murine secondary trophoblast giant cells. Reproduction. 128:53-71.

Haupt S, Berger M, Goldberg Z, Haupt Y. 2003. Apoptosis - the p53 network. $J$ Cell Sci. 166(20): 4077-4085.

Hogan B, Beddington R, Costantini F, Lacy E.1994. Manipulating the mouse embrio: a laboratory manual. $2^{\text {nd }}$ Ed. New York 
USA. Cold Spring Harbor Laboratory Press. Pp: 49

Horse KR et al. 2004. Trophoblast differentiation during embryo implantation and formation of the maternal-fetal interface $J$ Clin Invest. 114:744-754.

Jauniaux E, Hempstock J, Greenwold N, Burton GJ. 2003. Trophoblastic oxidative stress in relation to temporal and regional differences in maternal placental blood flow in normal and abnormal early pregnancies. Am J Patho.162:115-125.

James JL, Stone PR, Chamley LW. 2005. Cytotrophoblast differentiation in the first trimester of pregnancy: evidence for separate progenitors of extravillous trophoblasts and syncytiotrophoblast. Reproduction 130: 95-103.

John JC. 2002. The trasmission of mitochondrial DNA following assisted reproductive techniques. Theriogenology. 57:109-123.

Joswig A, Gabriel HD, Kibschull M, Winterhager E. 2003. Apoptosis in uterine epithelium and decidua in response to implantation: evidence for two different pathways. Reprod Biol Endocrinol. 1 (44):1477-7827.

Kiernan JA. 1990. Histological and histochemical methods. $2^{\text {nd }}$ Ed. New York USA. Pergamon Press. Pp:108; 345

Kimber SJ dan Spanswick C. 2000. Blastocyst implantation: The adhesion cascade. Cell \& Develop Biol. 11: 77-92.

Klobuear NK dan Gorup M. 2004. Histochemical investigations of NADPHand NADH-tetrazolium reductase Actvity in the Liver of Selenium annd Copper Treated Carp (Cyprinus carpio L.). Veterinarski Arhiv. 74 (5): 331-340.

Ludwig TE, Squirrell JM, Palmenberg AC, Bavister BD. 2001. Relationship between development, metabolism, and mitochondrial organization in 2-cell hamster embryos in the presence of low levels of phosphate1. Biol Reprod. 65: $1648-1654$.

Lunghi et al. 2007. Control of human trophoblast function. Reprod Biol Endo. 5:1477-7827.
Malik S, Sudoyo H, Marzuki S. 2000. Microphotometric analysis of NADHtetrazolium reductase deficiency in fibroblast of patients with leber hereditary optic neuropathy. $J$ Inherit Metab. 23:730-744.

Nadra K et al. 2006. Differentiation of trophoblast giant cells and their metabolic functions are dependent on peroxisome proliferator-activated receptor $\beta / \delta$. Mol Cell Biol. 26:3266-3281.

Nagai et al. 2006. Correllation of abnormal mitochondrial distribution in mouse oocytes with reduce developmental competence. J Exp Med. 210:137-144.

Norwitz ER, Chust, JS, Fisher JF. 2001. Implantation and the survival of early pregnancy. N Engl J Med. 345(19).

Summers MC , Biggers JD. 2003. Chemically defined media and the culture of mammalian preimplantation embryos: historical perspective and current issues. Hum Reprod. 9 (6 ): 557-582.

Straszewski-Chavez SL, Abrahams VM, Mor G. 2005. The role of apoptosis in the regulation of trophoblast survival and differentiation during pregnancy. Endocrine Reviews. 26 (7):877-897.

Tamassia et al. 2004. In vitro embryo production effciency in cattle and its association with oocyte adenosine triphosphate content, quantity of mitochondrial DNA, and mitochondrial DNA haplogrup. Biol Reprod. 71:697704.

Tayade C, Black GP, Fang Y, Croy BA.2005. Differential gene expression in endometrium, endometrial lymphocytes, and trophoblasts during successful and abortive embryo implantation. $J$ Immunology. 0022-1767.

Trimachi RJ et al.2000. Oxidative phosphorylation-dependent and independent oxygen consumption by individual preimplantation mouse embryos. Biol Reprod. 62: 1866-1874.

Turrens JF. 2003. Mitochondrial formation of reactive oxygen species. $J$ Physiol. 552: 335-344.

Vogel RO et al. 2005. Human mitochondrial complex I assembly is mediated by NDUFAF1. FEBS J. 272 : 5317-5326. 
Wang X. 2001. The expanding role of mitochondria in apoptosis. Gen \& Develop. 15:2922-2933.
Zess CJ. 2005. The apoptosis-necrosis continuum: Insights from genetically altered mice. Vet Pathol .40:481-495. 